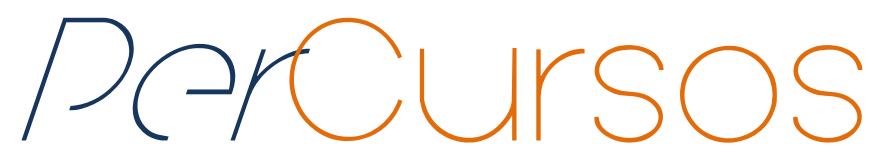

\title{
Gênero, mercado do sexo e migrações: entrevista com Adriana Piscitelli
}

\author{
Realizada por Gláucia de Oliveira Assis e Marlene de Fáveri em \\ $15 / 11 / 2013$.
}

Adriana Gracia Pisticelli é professora e pesquisadora da Universidade Estadual de Campinas - Brasil. Possui graduação em Ciências Antropológicas pela Universidade de Buenos Aires - Argentina (1979), mestrado em Antropologia Social pela Universidade Estadual de Campinas - Brasil (1990) e doutorado em Ciências Sociais pela mesma instituição (1999). É autora dos livros "Joias de família: gênero e parentesco em grupos empresarias brasileiros vinculados a famílias" (Editora da UFRJ, Rio de Janeiro, 2006) e "Trânsitos: brasileiras nos mercados transnacionais do sexo (EDUERJ/CLAM, 2013).

\section{Para citar este artigo:}

PISCITELLI, Adriana. Gênero, mercado do sexo e migrações: entrevista com Adriana Piscitelli [Entrevista realizada em 15 de novembro, 2013]. Revista PerCursos, Florianópolis, v. 15, n.28, p. 398 - 419. jan./jun. 2014. Entrevistadoras: Gláucia de Oliveira Assis, Marlene de Fáveri. 
Revista PerCursos: Então, Adriana, você é antropóloga, fez em 1979 antropologia em Buenos Aires, especializou-se em 88, fez mestrado em antropologia social na UNICAMP, doutorado também, em 99 terminou o doutorado. Vendo a sua trajetória, eu fiquei muito curiosa em pensar em perguntar o que a levou, o que a fez feminista ou, se não feminista, o que a levou a estudar as questões do feminismo e do gênero e depois o mercado do sexo também?

Adriana Piscitelli: Então, em termos de carreira... fiz graduação na Argentina, num momento delicado, final de um governo peronista e começo de um novo período de uma ditadura, na Faculdade de Filosofia e Letras da Universidade de Buenos Aires, que é onde funcionava o curso de Antropologia nessa cidade. Nesse período da ditadura se procurava evitar que nós fossemos a campo, inclusive para fazer trabalhos arqueológicos. Minha monografia de final de curso foi sobre socialização dos esquimós. Olha, com todo o campo que tínhamos para fazer em Buenos Aires! O governo tentou mudar o curso, transformando-o em algo histórico, trocou as disciplinas voltadas para a etnografia por outras voltadas para a história, para as pessoas não terem contato com as comunidades, porque consideravam que isso era politicamente perigoso. Quando eu acabei a graduação, uma antropóloga argentina que já morreu, chamada Ester Hermitte, empirista, estava chegando de Chicago e ela resolveu dar um curso de metodologia etnográfica, ela escolheu doze jovens antropólogos para formar. Ela ofereceu o curso num centro que tinha semelhanças com o CEBRAP em São Paulo. E eu fui uma das escolhidas. O curso era voltado para a metodologia etnográfica no âmbito da antropologia médica, e como eu me interessava por questões que tinham a ver com mulheres, resolvi fazer uma pesquisa sobre maternidade e reprodução social num bairro de periferia. E foi uma aprendizagem absolutamente extraordinária, porque ela nos ensinou tudo o que a faculdade não tinha ensinado: como montar um projeto, um roteiro de entrevista, como escrever um relatório. Tínhamos que levar as entrevistas e ela discutia de maneira crítica conosco, questionava se tínhamos feito as perguntas certas na hora que não devíamos, ou, ao contrário, se na hora que devíamos perguntar não perguntamos... Isso durou um ano, incluindo o relatório. E fazendo esse trabalho, 
procurando elementos teóricos para pensar sobre as questões de poder entre homens e mulheres naquele bairro da periferia, eu descobri a s antropólogas feministas. Nesse momento essa bibliografia não chegava às bibliotecas. Quando alguém viajava e trazia livros, era aquela festa, todos fazíamos xérox, fazíamos grupos de estudos com cinco capítulos ou artigos para discutir... Nesse momento, 1982, 1983, já era final da ditadura na Argentina, começou a se reorganizar o feminismo. Aí comecei a militar como ativista, mas minhas inquietações foram primeiro teóricas. Entrei num grupo trotskista-feminista (risos) chamado A.T.E.M., Associação de Trabalhos e Estudos sobre a Mulher, que era liderado por umas advogadas extraordinárias. E isso foi interessante, porque elas organizavam grupos de autoconsciência feminista nos quais as mulheres de classe média, universitárias, jovens, nos reuníamos com mulheres operárias, mais velhas. E nas reuniões havia um espírito muito festivo. Depois de todas aquelas discussões íamos para uma boate, o que era muito transgressivo naquela época, um monte de mulheres sair para dançar sem homens. Foi muito gostoso.

Revista PerCursos: E você veio depois trabalhar no Brasil? Veio fazer o mestrado no Brasil? Como foi essa vinda de Buenos Aires para o Brasil?

Adriana Piscitelli: Eu queria fazer pós-graduação e na Argentina não havia. Eu queria ter contato com uma antropologia latino-americana. E achava que isso seria possível no México ou no Brasil. Eu vim de visita ao Brasil. Tinha ido de férias, recém separada, a Salvador no ano anterior e eu amei, e pensei: vou fazer pós-graduação aqui. Descobri onde estava a [Universidade] Federal e fui lá de visita, perguntei onde estavam os antropólogos. Por acaso encontrei Cecília Sardenberg, novinha, que estava voltando de Boston e tinha duas crianças pequenas, e eu cheguei queimada de sol! (risos) "Eu quero fazer pós-graduação aqui." E a Cecília olhou pra mim e disse: "Pós-graduação no Brasil sim, mas em Salvador não!” (risos), e eu disse: “Por que não?”, e ela disse: “Ai, isso aqui é muito machista, você tem que ir pra USP, para UNICAMP ou para o Museu do Rio de Janeiro." No final do ano fui de visita a São Paulo, para a USP, para a UNICAMP, e fui ao Museu. E dos três lugares, o que eu mais gostei foi a UNICAMP, onde fui super bem recebida. Prestei primeiro na UNICAMP, passei e fui! Adorei a experiência e fiquei. 
Revista PerCursos: E foi na sua dissertação que você trabalhou com joias de família?

Adriana Piscitelli: Não... esse foi o doutorado. A dissertação foi uma pesquisa muito mais bonita que não foi publicada como livro. Foi no sul de Minas, em Monte Santo de Minas, de onde era uma querida colega de mestrado que me introduziu a essa cidade e às fantásticas narrativas de amor que nela circulavam na época, na metade da década de 1980.

Trabalhei com as duas famílias mais poderosas da cidade, de plantadores de café, analisando as articulações entre estratégias matrimoniais e o amor, num período de quase um século. A primeira parte foi com materiais de arquivos, cartas e fotografias, e na parte mais recente entrevistei várias pessoas que já eram idosas e outras mais jovens. Nessas entrevistas trabalhei com a primeira geração de mulheres que casou por escolha, fora dos casamentos arranjados, principalmente entre primos, para preservar o patrimônio, as terras. Elas narraram como se apaixonaram, como enfrentaram suas famílias. Algo muito bonito! Eu acho que foi a pesquisa da qual desfrutei. Eu não sei se essas fazendas ainda estão como eram na época em que fiz a pesquisa. São fazendas de finais do século XIX e inícios do século XX. Algumas eram de famílias de origem italiana que trouxeram artistas para pintar os tetos. Em algumas persistiam alguns elementos do período da escravidão, senzalas. No doutorado continuei com a questão da relação entre gênero e estratégias familiares de transmissão de patrimônio, mas com famílias de grandes grupos empresariais e com mais recursos teóricos. Mas quando eu estava na fase final do doutorado eu já estava querendo desistir, porque me interessava muito a questão do turismo sexual, mas minha orientadora, Mariza Corrêa, insistiu em que eu concluísse a tese com o seu tema original... Então fiz isso, mas solicitei financiamento para a pesquisa sobre turismo sexual antes de acabar a tese e quando a já tinha recursos para iniciar o novo projeto. Então, assim que depositei a tese, já comecei a pesquisa no Ceará.

Revista PerCursos: o que a levou se interessar pelo mercado do sexo? 
Adriana Piscitelli: Na verdade o meu interesse não era no mercado do sexo. Eu tinha um interesse teórico sobre o que hoje chamamos de intersecionalidades, mas no final dos anos 90 ainda essa denominação não estava tão difundida no Brasil. O meu interesse era na articulação entre gênero, raça e outras categorias de diferenciação e na relação entre países do Norte e do Sul. Eu frequento Fortaleza desde 1985, então acompanhei todo o processo de crescimento da cidade e da internacionalização do turismo. E o primeiro que me chamou atenção foi ver casais estrangeiros vindo para adotar crianças brasileiras. Eu ficava num hotel que derrubaram faz pouco tempo, que era um sonho porque era do final dos anos 60, muito simples, mas com um jardim desenhado por Burle Marx, com uma piscina imensa. Nesse momento, os casais estrangeiros tinham que passar um período de convivência com as crianças antes de poderem ir embora. E ficavam naquele hotel por causa da piscina e do jardim. Eu ficava olhando aquelas pessoas loiras com as crianças morenas, e aquilo me produzia certa sensação de violência. Num edital para um concurso de pesquisa apresentei um projeto sobre essa temática, que não foi aprovado. Então, em outro enviei um projeto envolvendo as relações entre Norte e Sul, mas voltado para o turismo sexual. E foi aprovado. E foi assim que eu cheguei ao mercado do sexo, mas o meu interesse estava na questão das intersecionalidades e das relações de poder entre países do Norte e do Sul. E a problemática do turismo sexual, para minha surpresa, estava carregada de ambiguidades e me conduziu novamente aos namoros e casamentos. De fato, minhas pesquisas entraram pesadamente na problemática da indústria do sexo só quando fui trabalhar na Espanha com trabalhadoras sexuais brasileiras nesse país, em 2004. Primeiro eu segui as mulheres de Fortaleza que foram para a Itália, convidadas por turistas italianos. Isso deixou claro para mim que havia vários caminhos possíveis para essas mulheres, algumas iam fazer programa na Itália, mas o resto estava procurando deixar o mercado do sexo e migrar mediante o casamento. Elas formaram suas famílias e estão casadas até hoje.

Revista PerCursos: Num certo sentido você continuou pesquisando os afetos e acho que essa leitura, pelos afetos, pelos casamentos, pela busca da autonomia, contribui para uma outra leitura da mobilidade feminina. Acho que em seus trabalhos você mostra como 
a discussão do turismo sexual, num certo sentido, dá uma visão muito moralista da circulação das mulheres. Queria que você falasse um pouco sobre isso: como que é pesquisar o turismo sexual e fazer esse distanciamento e esse estranhamento para poder desconstruir essa ideia de que o perigo é a circulação de mulheres, que o perigo é elas serem enganadas? Como você vê a agência das mulheres que tentam buscar alternativas para suas vidas e as dificuldades que elas efetivamente encontraram ao escolher esse caminho?

Adriana Piscitelli: Os processos de pesquisa são interessantes. Quando eu comecei a pesquisar a problemática do turismo sexual, eu de fato compartilhava as ideias de um feminismo radical que via essa problemática como pura exploração, considerava as mulheres como vítimas e esses homens como monstros. Mas, o trabalho empírico foi me mostrando que a realidade era infinitamente mais complexa do que isso, que elas podiam construir espaços de autonomia dentro de certas margens, mesmo naqueles encontros. $\mathrm{E}$ esses turistas, realmente eu cheguei a ficar próxima de vários deles. Alguns me provocavam rejeição, eles queriam apenas transar e transar e não davam a mínima pra nada. Tinham ido para outros lugares de turismo sexual e Fortaleza era mais um. Mas tinha outros que não. Eram homens que não tinham sido bem sucedidos em termos amorosos e sexuais em seus países de origem. Queriam namorar, ter família, e olhavam pras meninas e pensavam: "Elas não são prostitutas, elas não tiveram sorte, são pobres, estão precisando de alguém que ofereça uma oportunidade". E em muitos dos casos era verdade. Esse processo, em Fortaleza, para mim foi relativamente tranquilo, porque fui acompanhando o que o campo ia me mostrando. A fase de pesquisa na Itália foi mais complicada. Porque meninas que eu conheci em Fortaleza e que via como muito autônomas - e já as conhecia fazia uns anos - que passavam a madrugada fora, que trabalhavam, que voltavam de mototáxi para casa, me gritavam quando passavam pela janela do hotel: "Tchau, até amanhã!" As via como meninas que namoravam e se divertiam. Quando cheguei na Itália, as encontrei feitas umas donas de casa. A minha entrevistada mais próxima, - acho que toda pesquisa tem alguém que é central - em um ano que tinha passado na Itália tinha engordado dez quilos, ela tinha um cabelo lindíssimo, encaracolado, até a cintura, e o tinha cortado no ombro, colocou uns óculos 
grossos. Era assim uma mudança brutal e eu vi elas... como acanhadas, um pouco submetidas a esse mundo familiar. Para mim, elas eram mais interessantes em Fortaleza. E quando conversei de uma maneira indireta com elas, mas elas entenderam perfeitamente o que eu estava querendo dizer, elas diziam: "Não, mas você viu o lado da diversão, mas às vezes a gente não tinha dinheiro pra voltar para casa e transava com alguém para ter o dinheiro para um mototáxi e ficava com alguém que não era interessante. Sim, tinha a parte da diversão, das brincadeiras, mas isso aqui é uma vida muito melhor, é uma vida segura." Então assim, eu tive que fazer um esforço maior para compreender essa passagem que à primeira vista parecia como uma renúncia à autonomia, para ter algo seguro, para poder enviar dinheiro para o Brasil, mas o esforço para construir algo diferente no Brasil parecia ser realizado ao custo de uma certa submissão na Europa. Não estou dizendo que os maridos não gostassem delas, de fato todos eles eram apaixonados por elas, nem que as maltratassem, mas elas, no meu olhar, tinham virado donas de casa. E estavam entrando numa fase de fazer imensos esforços para engravidar, depois tiveram seus filhos. Mas não via movimentos de esforços para aprender italiano nem de lutar para trabalhar fora de casa, nada disso.

Revista PerCursos: Parece que o movimento de autonomia foi no sentido de sair de Fortaleza, ou de sair do mercado do sexo e de conseguir um relacionamento...

Adriana Piscitelli: Todas elas casaram com homens que eram jovens, que tinham um salário médio... todos tinham casa própria em Milão, o que é uma coisa muito cara, mesmo que fosse na última estação do metrô. Eles tinham salários que iam de dois a três mil euros. No caso da minha principal entrevistada, a lua de mel dela foi nas Maldivas, ganhou seu anel de brilhante, teve uma super festa, escolheu um vestido de veludo vermelho com um salto altíssimo. E cada um desses elementos fazia parte da expressão do seu sucesso. E para mim foi difícil compreender como a participação no mercado do sexo fazia parte desses desejos de estabilidade no âmbito de uma vida mais estável, dentro de um padrão heteronormativo que, do meu ponto de vista, era conservador. Por isso quando me perguntam: "Bom, mas você vê essa participação no mercado do sexo como resistência?", eu sinceramente não vejo. Eu acho que dentro do leque de opções 
que elas tinham disponíveis escolheram o que acharam que oferecia mais possibilidades, acho que há agência, sim, mas não necessariamente resistência nem contestação às normas.

Revista PerCursos: Elas saíram da norma pra voltar, num certo sentido em que nessa sociedade em que elas vivem se inserir no mercado do sexo é uma forma de enfrentamento, é um trabalho desrespeitado, não reconhecido, então elas se casam com os europeus para poder se reinserir na sua família e nas normas. A ideia do filho...

Adriana Piscitelli: Eu vejo assim: nenhuma de minhas entrevistadas do universo no qual trabalhei em Fortaleza que foi para Itália diria que era uma prostituta profissional. Varias delas inclusive se envolviam em relações de sexo transacional, e não faziam exatamente programas. Eram garçonetes, eram arrumadeiras de hotel e tinham essas relações com estrangeiros que as "ajudavam”. Outras sim faziam programas, mas mesmo assim não era algo muito profissional, nem elas se viam como profissionais. Já o universo de entrevistadas com as quais trabalhei na Espanha estava constituído por mulheres que sim se consideravam assim... Várias tinham sido prostitutas no Brasil, sobrevivendo exclusivamente do trabalho sexual, e foram para a Espanha para ganhar mais dinheiro na prostituição. Eram trabalhadoras do sexo que se pensavam como prostitutas, tinham orgulho da profissão e que tentavam se organizar. Era um universo inteiramente diferente. E neste universo há uma contestação maior a uma série de normas, elas contestam vários aspectos da heteronormatividade de uma maneira que o universo com o qual trabalhei em Fortaleza não fazia.

Revista PerCursos: Qual seria a diferença? Por que você acha que é assim?

Adriana Piscitelli: É necessário pensar que a ideia de mercados do sexo é muito ampla e engloba relações muito diferentes. Trabalhar na indústria do sexo e defender a prostituição como trabalho requer uma postura muito diferente. Eu estava lendo um trabalho extraordinário de uma mulher que se chama Rutvica Andrijasevic que trabalhou com mulheres do leste europeu na Itália. A problemática que interessava a ela era o tráfico de pessoas, e isso a conduziu para os abrigos destinados a elas. E todas as 
mulheres que ela conheceu nos abrigos, que trabalhavam na prostituição de rua e trabalhavam para terceiras partes, ou seja, tinham um cafetão que vinha e pegava o dinheiro e tal, nenhuma delas suportava a ideia de pensar-se como prostituta. O estigma era pesado demais. Então elas jogavam com várias coisas para não serem estigmatizadas. Que tinham trabalhado na prostituição porque tinham se apaixonado, e o namorado exigiu ou para sustentar o filho. Isto é algo muito diferente de uma mulher que diz [batendo na mesa]: “Não, eu sou trabalhadora do sexo, eu tenho minha associação aqui, meu marido sabe e respeita, porque, veja, uma coisa é uma coisa e outra coisa é outra coisa" (risos). Mesmo que essas mulheres estejam casadas, tenham famílias, o posicionamento delas, o posicionamento frente ao trabalho sexual, as relações de solidariedade que estabelecem com travestis e transexuais, tudo isso conduz a um maior questionamento das normas.

Revista PerCursos: É interessante. Foi nesse olhar e nesse contexto que você foi trabalhando o tráfico de pessoas mais especificamente?

Adriana Piscitelli: A questão do tráfico foi se impondo para mim. O primeiro grande seminário que teve sobre tráfico foi em São Paulo, antes da ratificação do Protocolo de Palermo. Foi em 2003. Me convidaram e eu expliquei que não tinha trabalhado com tráfico de pessoas, mas com turismo sexual. Quiseram que eu participasse mesmo assim. Eu falei vinte minutos sobre turismo sexual e migração, e quando acabei vieram as perguntas: “Essas mulheres são traficadas como?” e eu falei: “Não, veja, não usei a palavra 'tráfico' nem 'traficada', eu falei o tempo todo sobre migração”, e continuaram me perguntando como se eu nunca tivesse falado em migração. Daí percebi que havia um problema aí que precisaria ser enfrentado.

Revista PerCursos: Há uma tendência a confundir migração com tráfico de mulheres? Adriana Piscitelli: Sim, e nesse momento ficou muito claro. Aí eu resolvi tentar mostrar as diferenças entre tudo aquilo e o que estava sendo pensado como tráfico. 
Revista PerCursos: Hoje nós temos um plano nacional de enfrentamento ao tráfico de pessoas e já está na terceira ou quarta reunião. Mas como nós podemos pensar as possibilidades e limites desse plano, se você o conhece?

Adriana Piscitelli: Olha, foi elaborado o segundo plano. A política é a mesma, mas o plano é diferente. Eu não o estudei ainda com a suficiente profundidade para dar uma opinião sobre as diferenças entre ele e o primeiro plano. Mas algo que me chamou a atenção no primeiro plano e também na política é que está prevista a atenção e proteção das vítimas de tráfico no Brasil mesmo que sejam estrangeiras. E nos estudos de nosso grupo de pesquisa começaram a aparecer casos de pessoas estrangeiras que, mesmo sendo potenciais vítimas de tráfico de pessoas, foram deportadas. E há evidências de que um dos efeitos das políticas antitráfico tem sido restringir as mobilidades de algumas brasileiras ao exterior, mulheres jovens, que aparentam ser de classes populares e são vistas como de pele mais escura. Ao mesmo tempo, em diferentes lugares, as blitze para detectar casos de tráfico ou de exploração sexual tiveram efeitos em termos do controle migratório e no exercício da prostituição. Na Europa, esse movimento era muito claro, com todo o processo de "securitização" das fronteiras, as medidas contra o terrorismo e contra a migração irregular. Tudo isto não fazia um sentido análogo no Brasil. No entanto, começamos a ter um processo de securitização também no Brasil, que coincide com a chegada dos haitianos, com a intensificação da preocupação com as fronteiras, que se expressa na realização das pesquisas sobre tráfico nas fronteiras, como aquela que acaba de ser concluída. E paralelamente o que começa a aparecer em narrativas de diferentes agentes é a falta de proteção às vítimas estrangeiras no Brasil. Por exemplo, num encontro recente, integrantes de uma organização não governamental contaram que no Estado delas, uma boate, havia vinte meninas paraguaias, e mais da metade era menor de idade, e tecnicamente isso é tráfico de pessoas. No entanto, elas foram colocadas num ônibus e enviadas para o Paraguai. De acordo com essas narrativas, nesse estado teve um par de trabalhadores escravos de Bangladesh, que também foram deportados. São relatos, não tenho confirmação desses casos. No entanto, mais ou menos coincidentemente com esses relatos, em 2012 ou 2011, o Conselho Nacional de Migração formula uma recomendação, para que a polícia não deporte vítimas de tráfico de pessoas. 
Isso quer dizer que se reconhecia que elas estavam sendo deportadas. Então, o debate e as ações voltadas para o tráfico de pessoas têm vários problemas. Um deles é a confusão conceitual. E outro problema é que não há apoio para as pessoas consideradas como vítimas, nem sequer no sentido de poder abrigá-las. O que quero dizer é que esses problemas vão além da questão de controlar a prostituição e da restrição da circulação de mulheres, principalmente pobres e negras. Acho que já se criou um "dispositivo do tráfico de pessoas", que produz vítimas que estão no limiar entre serem vítimas e criminosas, e esse dispositivo tem efeitos bastante negativos sobre essas pessoas, que dificilmente recebem apoio. Em 2012 Marcia Anita Sprandel, Jose Miguel Olivar e eu organizamos uma oficina sobre tráfico de pessoas na ANPOCS, que foi interessante, na qual participaram pessoas que apoiavam trabalhadoras sexuais, migrantes e que trabalharam com pessoas que se envolveram no tráfico de órgãos. Entre elas estavam Paulo Illes, Gabriela Leite, uma travesti interessante, Pâmela, de Uberlândia, e Julio Lindemir. E havia um claro acordo entre todos: o dispositivo do tráfico não tinha sido bom para nenhuma dessas categorias de pessoas, e a ideia era que teria sido bem melhor reforçar os direitos de cada categoria particular.

Revista PerCursos: Para as pessoas em situação de tráfico.um certo sentido a discussão do tráfico de pessoa acaba criminalizando os migrantes?

Adriana Piscitelli: Totalmente! Então assim, nenhum de nós estava dizendo que não tinha em cada uma das áreas diferentes trabalho forçado, situações de exploração, de confinamento, de violência. Mas o dispositivo do tráfico não parece oferecer boas ferramentas nem o melhor caminho para lutar contra isso. Ao contrário, parece que contribui para que se capilarize cada vez mais, expandindo os efeitos negativos.

Revista PerCursos: A novela mostrou exatamente essa forma. Não sei se você viu a novela de Rede Globo.

A.: Um pouquinho... 
Revista PerCursos: Pois é, aquele pouquinho que me interessava também. Me interessou aquele pouquinho para pensar isso. Eu achei que fez uma representação muito errada das mulheres. Então foi justamente isso.

Adriana Piscitelli: A minha principal entrevistada entre as trabalhadoras sexuais brasileiras na Espanha trabalha em Barcelona. Ela tinha vindo passar as férias no Brasil. Eu perguntei a ela sobre a novela esse ano, quando a encontrei, em abril. E ela me disse: "Ah sim, eu assisti. Eu gostei.” Então perguntei: “Do que você gostou?”, e ela me disse: “Ó, da parte da prostituição não, isso não existe! É tudo mentira! Mas o que eu gostei foi da delegada!" Eu perguntei para muitos o que acharam da novela e pessoas que trabalham com tráfico gostaram porque acharam que sensibilizou as pessoas. Eu acho complicado porque sensibiliza as pessoas através de umas situações que são raras, são extremas. E faz com que não se levem em conta as outras situações de violência que são muito mais próximas. Enfim, acho que a novela só contribui para que você tenha que ter uma vítima desse tipo para pensar que se trata de uma pessoa com problemas. E isso é muito complicado.

Revista PerCursos: O que é difícil nessa história, pegando o caso da fronteira do Brasil com a Venezuela, em questão dos haitianos. É que como se chama tudo de tráfico, toda tentativa de mobilidade, de cruzar fronteiras, não se consegue ver o que é efetivamente tráfico e não se atende humanitariamente aqueles que estão precisando cruzar a fronteira. Eu volto a falar da criminalização da migração. Parece que na fronteira, raça, gênero e nacionalidade se articulam, marcando aqueles que se está querendo barrar: os haitianos. Não são os espanhóis e portugueses. Queria que você falasse um pouco disso.

Adriana Piscitelli: A Joana Plaza tem um trabalho muito interessante nesse sentido. Mostrando, a partir de atas do Conselho Nacional de Migrações - ela disse que há online como essa intersecionalidade que marca os menos desejados se vincula com a língua. Em relação à questão do tráfico, eu perdi um pouco as esperanças de interferir de maneira positiva no debate. Porque o dispositivo do tráfico se retroalimenta e se expande. Se num determinado momento a influência de instâncias das Nações Unidas era muito clara, agora a situação é mais complexa. Virou uma questão para o Estado, um problema de 
segurança, uma questão para a Igreja Católica. Então, como que você interfere nisso? E a questão dos direitos dos migrantes se torna cada vez mais complicada, mesmo porque o Brasil está atraindo migrantes agora. Você vê que tem paralelamente a questão do controle das fronteiras e xenofobia. Está tendo caso de xenofobia nas escolas, que era uma coisa muito rara no passado.

Revista PerCursos: Eu acho que a xenofobia também foi aguçada por essa história do Programa Mais Médicos. Não é que ela não existia anteriormente. E novamente os haitianos, os cubanos... São populações negras e latino-americanas pobres.

Adriana Piscitelli: Nossa! Agora a reação contra os cubanos para mim é extraordinária porque se sabe que Cuba tem um dos melhores sistemas de saúde do mundo!

Revista PerCursos: E o mais interessante é que os cubanos vieram na década de 90 no governo Fernando Henrique Cardoso, e não foi feito nenhum alarde. Vieram em circunstâncias semelhantes, de suprir a falta de médicos. Passou em branco. Sem nenhum alarde.

Revista PerCursos: Eu acho que é um momento político muito específico e especial.

Adriana Piscitelli: É muito especial sim. E é um momento conjuntural também, muito particular. Quando eu voltei à Espanha, em 2013, me surpreendi, porque vários brasileiros qualificados que estavam dando aula na Espanha tinham prestado concurso no Brasil e voltado para o país. E encontrei uma imensa demanda de espanhóis para virem ao Brasil. Então, por exemplo, a escola de português vinculada ao consulado não tinha mais vaga nem lista de espera. Abriam mais escolas paralelas. No início eram empresários que frequentavam as escolas, mas depois foram se incorporando cozinheiros, garçonetes, querendo vir para o Brasil por causa das Olimpíadas e da Copa do Mundo e etc. Várias pessoas que me indicaram para entrevistar já estavam no Brasil, em Campinas, no Rio de Janeiro. Em Campinas há vários espanhóis, alguns casados com moças brasileiras. E na Espanha me encontrei com dois aspectos novos: compra de casamentos por parte de pessoas espanholas com pessoas brasileiras, e também encontrei trocas de casamentos, e isso é extraordinário porque fala de uma equivalência geopolítica. Assim, uma mulher 
que queria ter papéis brasileiros pra ter acesso a financiamentos do Governo e o homem queria os papéis espanhóis para ficar trabalhando lá. Então é uma troca, ninguém pagou nada, e remete ao mais interessante que estou encontrando neste momento. Não sei ainda se esses novos movimentos, em termos de casamento, estão acompanhados por alterações no imaginário sobre os dois países. É isso que estou tentando analisar neste momento.

\section{Revista PerCursos: Tanto entre os brasileiros quanto entre os espanhóis?}

Adriana Piscitelli: A percepção dos espanhóis sobre os brasileiros, especialmente. Eu tenho uma amiga que mora na Espanha e é de Uruaçu, em Goiás; ela é faxineira. Durante muitos anos ela chorava, chorava, porque as vizinhas dela de Uruaçu foram trabalhar como prostitutas e fizeram muito dinheiro e ela chorava porque não tinha coragem de ser prostituta, só faxineira, então ela ganhava muito menos. E o que ela me dizia era que tinha saído uma matéria sobre as prostitutas em Belo Horizonte que estavam aprendendo inglês para se preparar para os grandes eventos, e que todas as patroas dela, em Barcelona, comentavam aquilo: "Tudo bem, as coisas no Brasil podem ter mudado, mas aqui coisa ruim gruda e fica!”. Apesar disso eu vi uma diversificação. Uns anos atrás, na mídia na Espanha, as matérias sobre o Brasil tendiam a ser sobre prostituição, vítimas de tráfico, violência de gênero, migração irregular. E em 2013 havia diversas matérias sobre crescimento econômico, sobre redução das desigualdades, sobre aspectos culturais. Também havia notícias sobre o mensalão, mas pouco. Era algo bem mais positivo. Eu não sei como continuou, porque os eventos de junho causaram impacto no mundo inteiro.

Revista PerCursos: O efeito das passeatas de junho sobre esse imaginário?

Adriana Piscitelli: Sim, eu me refiro a uma mudança de imaginário num momento no qual a crise na Espanha estava no pico, era algo violento. As pessoas sendo despejadas, se suicidando porque eram despejadas das casas, a perseguição às prostitutas, a queda do mercado do sexo que não tinha mais clientes. Paralelamente, muitos relatos sobre a emigração de jovens espanhóis. Agora no Brasil não ouvimos falar sobre esses espanhóis, como entraram, como permaneceram. Mas temos notícias dos haitianos quase todos os 
dias. Quantos estão naquele abrigo, quanto se gasta para se dar as quatro refeições diárias, etc. Por outro lado, acho que tem um movimento no que se refere às migrações que é interessante. Estão tentando reformular as leis e tem muita discussão.

Revista PerCursos: Eu participei de um seminário em Foz do Iguaçu para discutir a mudança na lei migratória e foi bem interessante. Mas a tensão que tem na discussão da lei migratória é a mesma tensão que tinha na década de 80 . A segurança nacional e os direitos humanos. Como garantir a segurança nacional, e eu estou falando na lógica da Polícia Federal que estava lá participando junto, e entender a migração na ótica dos direitos humanos. Para a Polícia Federal, migração é uma questão de polícia, não de direitos. Assim, grosso modo, porque não é todo mundo que pensa assim. Mas foi muito interessante. No seminário tinha o pessoal da Polícia Federal, o pessoal do Ministério da Justiça, o pessoal que trabalha com os migrantes, então foi muito interessante ver essa tensão entre segurança das fronteiras e direitos humanos. E acho que é um desafio mesmo.

Revista PerCursos: São pessoas contemporâneas muito presentes, que precisam ser trabalhadas, discutidas e pesquisadas. A gente não pode deixar assim porque é uma xenofobia muito grande que vem vindo. Você trabalhou com o mercado do sexo, trabalhou e trabalha com a questão do tráfico internacional etc., e fez alguns trabalhos sobre turismo sexual e internet e como que o turismo sexual acaba usando a internet como uma ferramenta na contemporaneidade. Você fez esse trabalho acho que em 2006, 2007. Mas a pergunta é a seguinte: você vê isso hoje em 2013, mais recentemente, como podemos pensar o uso da internet como fonte de pesquisa?

Adriana Piscitelli: Sobre a questão do turismo sexual, eu não sei como está hoje porque eu não tenho mais acompanhado. Naquele momento era uma ferramenta extraordinária no sentido de abrir caminhos para novos turistas sexuais, de produzir novos lugares alvo. Era fascinante.

Revista PerCursos: Quando você fala “fascinante", é fascinante enquanto uma ferramenta para trabalhar? 
Adriana Piscitelli: Não, era fascinante como eles utilizavam a internet para abrir novos caminhos na geografia do turismo sexual. Como iam incorporando lugares da África, como iam erotizando certas regiões e deserotizando outras. Então, para mim é muito interessante quando eu ouço as ideias das pessoas da Amazônia que trabalharam, por exemplo, com mulheres amazônicas que ofereciam serviços sexuais na Espanha. E falam: “As representações que se têm das mulheres amazônicas é que são tão quentes". E eu pensava quem tem essas representações, os consumidores de sexo espanhóis. Porque para os espanhóis, de onde vêm as brasileiras não faz a menor diferença, são brasileiras, e se for julgar pelo que aparecia no site de turismo sexual, há uma produção de imaginário que não valoriza o indígena. Então os sites foram fascinantes para entender como rapidamente ia se erotizando um lugar e como isso ia trazendo turistas. E como, nesse processo, as práticas sexuais eram relativamente irrelevantes nesse universo. Era muito mais interessante escolher um lugar novo, um lugar virgem, exótico, do que as práticas em si, um lugar "off the beaten track", ao qual ninguém foi ainda, etc. Outra coisa é quando as trabalhadoras sexuais utilizam a internet, e utilizam cada vez mais - na Espanha quase não se publicam anúncios sexuais no jornal, tudo aquilo que era via jornal agora é via internet -, e eles, as trabalhadoras e trabalhadores sexuais, gastam muito tempo para se produzirem, para fazerem as fotografias, e muito dinheiro, porque não é barato manter isso, nos sites específicos. Acho que a internet como ferramenta para pesquisar os mercados do sexo é muito interessante, porque permite perceber uma diversidade de diferentes aspectos, incluindo dinâmicas desses mercados, que se alteram muito rapidamente.

Revista PerCursos: Eu tenho estudado desde 2006 aquela mudança do mercado do sexo, do programa feito da noite para o dia. Como se tornou diurno o programa e como em Florianópolis eu fui recolhendo desde 2005 bilhetinhos anunciando produtos, fotografando motéis, todo lugar que eu vou... e os motéis estão colocando na frente: "Venha das nove às cinco da tarde que é mais barato", com outras palavras. Isso no Brasil inteiro e em outros lugares que eu tenho viajado, inclusive no México. E é uma outra dinâmica, além de se transformar em diurno porque a clientela tá buscando no período 
diurno, tem essa questão da internet também. Nos jornais eu também percebi que eles não têm... os nossos jornais de Florianópolis tinham duas ou três páginas de anúncios sexuais. Hoje tem uma tirinha só, e quando tem. Isso no Brasil inteiro, porque eu compro jornal em todo o lugar que eu vou para perceber isso. Agora migraram para a internet, além dessa questão do diurno que é muito interessante.

Adriana Piscitelli: Eu não sei, acho que tem também aqui no Brasil site de clientes, em que os clientes conversam. Eu já ouvi muitos questionamentos, relativos à falsidade dos depoimentos, por serem as próprias meninas que escrevem como se fossem os relatos deles... Mas isso para mim não é relevante, porque o interessante é o imaginário que está sendo produzido na internet, porque é um espaço onde estão os anúncios, os relatos de interações.

Revista PerCursos: Em Florianópolis eu acompanho desde 2005, agora não acompanho mais muito, mas eu ia durante muito tempo nos sábados, principalmente no verão, às 10 horas da manhã para o centro da cidade e ficava andando na Felipe Schmidt, numa das principais ruas, e ficava recolhendo os bilhetinhos. Eu escrevi o artigo. E hoje quando vou no centro ainda pego os bilhetinhos, guardo, e meus alunos também me trazem. Vou voltar a escrever daqui a dois, três anos para ver essa dinâmica, para ver o que mudou. Mas estou guardando essas fontes. E juntando isso quero ver se a popularização da internet vai diminuindo os bilhetinhos da rua. Dizem que são muito eficazes esses bilhetinhos. Porque eles entregam e levam o cliente até o prédio.

Adriana Piscitelli: Deve ser, porque, se não, por que fariam tanto? Porque tem uma lógica.

Revista PerCursos: Sim, é tudo medido, é eficiente. A pessoa está andando na rua apressada, daí chega o menino, entrega, ele olha... o menino ganha um percentual se ele conseguir levar o cliente até o lugar dos programas. Isso foi uma das estratégias que encontrei no centro de Florianópolis. E as moças, como elas se comportam em relação a isso. No artigo escrevi: "Mentir para quê?", se elas mentem, chega na hora e elas têm que botar fotografia delas. Na Argentina isso é muito forte, elas põem a bunda! É impressionante, quero trabalhar a Argentina. Quero fazer um pós-doc! (risos) 
Revista PerCursos: Eu acho interessante essa interseção, pensar um pouco a ideia de gênero, migração e a questão dos mercados. Não diria dos mercados, mas dos afetos. E eu gosto muito do seu trabalho porque você consegue trazer isso pensando nos afetos, nos arranjos matrimoniais, nos namoros e no mercado do sexo. E acho que quando você faz isso permite mostrar um pouco a complexidade que é a ida das mulheres migrantes quando elas optam por migrar. E acho que contribui para desconstruir uma certa imagem, tanto de vítima quanto de perigo. Mas, de qualquer maneira, essas mulheres estão numa situação desigual. O que você acha?

Adriana Piscitelli: Totalmente! Quando elas estão migrando para a Europa, por exemplo, não necessariamente por causa da situação irregular, mas por muitas outras coisas, como critérios de classe, de origem, faz toda a diferença. $E$ também por questões relacionadas à cor da pele. Porque, Gláucia, isso é um jogo complexo. Se por um lado o fato de ser brasileira, independentemente da cor da pele, racializa, por outro lado, em lugares como a Espanha, se você é o que as pessoas veem como negra ou as pessoas classificam como negra, a racialização é muito mais intensa e negativa. Aquele lado do jogo positivo que se abre, que dá possibilidades de utilizar essas classificações de maneira estratégica, se interrompe quando se trata de pessoas negras. Então há um limite muito sério ali. Então, o que me interessa nas pesquisas que estou realizando no momento atual é ver se, nas migrações dos espanhóis para o Brasil, procurando um futuro melhor, nas relações que estabelecem com brasileiras, o posicionamento desigual delas se altera. Quero dizer, se o contexto atual desloca as relações entre Norte e Sul tal como as conhecemos até o momento. E aqui há outro problema, e é o referencial teórico. Eu não achei um referencial que me ajude a pensar em possíveis deslocamentos, porque a teoria póscolonial foi pensada considerando a permanência do Sul global num lugar subalternizado. Circulando fora eu não sei que caminho vai seguir o Brasil, mas tenho a impressão de que talvez, no que se refere a este país, a ideia de sul possa se tornar um lugar apenas geográfico. E aí precisaremos de teoria para acompanhar esses movimentos. Por isso eu falava da diversificação de percepções sobre o Brasil na Espanha, do desespero dos espanhóis em acharem trabalho no Brasil. E mesmo que você explique que há trabalho, mas que não se paga como já se pagou na Espanha, aqueles trabalhos na construção que 
as pessoas podiam ganhar quatro ou cinco mil euros por mês. Aquilo que você me falava da desigualdade... eu acho que em todo esse período, entre as migrantes brasileiras com as que trabalhei na Espanha, havia uma desigualdade intensa nos relacionamentos com homens espanhóis, da qual só se salvavam brasileiras que eram de classe média alta. Viajaram como estudantes de pós-graduação, casaram com pessoas de nível socioeconômico equivalente. Mesmo que em algum momento tivessem sido subalternizadas, não havia uma relação de desigualdade com os seus namorados, maridos, equivalente. Isso era muito forte nos relacionamentos de mulheres de classe média para baixo e das mulheres que se consideravam negras. Mas tem uma diferença imensa entre uma morena clara e uma morena negra na Europa. O fenótipo faz toda a diferença na maneira como as mulheres são tratadas e em suas possibilidades de inserção.

Revista PerCursos: Os dados do IBGE dizem isso. Dizem isso sobre renda, dizem isso sobre mercado matrimonial.

Adriana Piscitelli: Isso também aparecia na questão das inadmissões na Europa. Quando fizemos as pesquisas com deportados e não admitidos na Europa que retornavam ao Brasil através do aeroporto de Guarulhos, víamos que as mulheres não admitidas, que não chegavam a atravessar a fronteira, eram majoritariamente negras, enquanto que as deportadas, que em algum momento ingressaram em países europeus e mais tarde foram deportadas, eram brancas ou morenas claras. Conseguiram entrar, permanecer um tempo e em algum momento a polícia as descobriu e as deportou. As outras simplesmente não entravam.

Revista PerCursos: E as deportações que deram o escândalo da crise das deportações foram de mulheres brancas de classe média. Não que as deportações estivessem corretas. O que eu quero dizer é que ganhou mais reconhecimento.

Adriana Piscitelli: Eu fiquei impressionada com isso, porque fazia anos que denunciávamos o problema das não admissões e das deportações, e ninguém prestava atenção. Bastou que fosse uma estudante de pós-graduação com boas conexões sociais para que 
ganhasse lugar na mídia e as pessoas se revoltassem. Mas então, Gláucia, acho que estamos num momento de alterações significativas, e não sei se estamos conseguindo perceber. É sério.

Revista PerCursos: Até porque nessa migração de retorno com acompanhante estrangeiro, fica invisível o acompanhante.

Adriana Piscitelli: É verdade. Estive em Fortaleza, recentemente. Encontrei pessoas novas, brasileiras que casaram com estrangeiros na Europa e que, depois da crise, voltaram com eles. Eles venderam as propriedades, tentaram se instalar em Fortaleza. Um par de anos atrás, vi algo parecido em Belém, mostrado por Marcel Hazeau, que estava defendendo uma dissertação sobre migração de brasileiras a partir dessa cidade. Ele trabalhou num grande bairro da periferia de Belém - próximo da universidade. Ele trabalhou com algumas mulheres que foram para o Suriname, mas muitas foram para a Europa, e elas voltaram com seus maridos europeus e se instalaram na periferia. Tem o bar do holandês... do inglês... Acho que deveríamos levar isso a sério, fazer um levantamento pelo Brasil, pelos diferentes estados sobre estrangeiros, e estrangeiros casados com brasileiras, e ver o que está acontecendo.

Revista PerCursos: Para encerrar, nós estamos no seminário aqui, teremos uma mesa. A gente não está dando conta de pensar teoricamente essas mudanças nos fluxos, mas pensando aqui no Fazendo Gênero e na nossa mesa de feminismo transnacional e migrações (risos)...

Adriana Piscitelli: Foi uma pergunta difícil que você criou! (risos)

Revista PerCursos: Como é que você acha que o feminismo transnacional pode nos dar elementos para pensar justamente esses locais que não se encaixam na teoria ou para compreender essas realidades? Que diálogo que é possível?

Adriana Piscitelli: Eu acho que será possível um diálogo num momento em que se levem de fato em conta as realidades locais. 
Revista PerCursos: Acho que esse é o desafio.

Adriana Piscitelli: O que eu vejo dos feminismos transnacionais... Eu ainda gosto das primeiras formulações dos feminismos transnacionais, que dialogam com os feminismos pós-coloniais. Acho que elas dão ferramentas teóricas para nós pensarmos a partir dos lugares locais. Mas estas grandes redes de feminismos transnacionais com aquelas ideias, como por exemplo o combate ao tráfico de pessoas confundindo-o com prostituição e ignorando a criminalização da migração que promove, acho que são muito mais nefastas que úteis. Funcionaria levando seriamente em conta as realidades locais e ouvindo as mulheres. E uma coisa estranha que os feminismos transnacionais às vezes fazem é não ouvir. E quando se trata de migrantes, não ouvir aqui e não ouvir fora. E isto se torna ainda mais complicado quando esses feminismos transnacionais se articulam com os feminismos do Estado. Por isso gostei tanto de ver os resultados da Secretaria de Políticas para as Mulheres, com o resultado do 180 internacional, indicando que o principal problema das brasileiras que moram no exterior não é o tráfico, mas a violência doméstica, os jogos de poder que fazem com que os maridos tenham o poder de ficar com as crianças em caso de separação. Então o termo feminismo transnacional se tornou também uma armadilha e eu acho que o único jeito de fato é perceber que há muitas realidades locais. Claro que é possível criar alianças a partir das realidades e problemas locais, não por cima, não de fora... Eu acho que o caminho é esse: dar atenção às mulheres e às suas realidades. 
Recebido em: $04 / 04 / 2014$ Aprovado em: 29/05/2014

Universidade do Estado de Santa Catarina - UDESC

Centro de Ciências Humanas e da Educação - FAED

Revista PerCursos

Volume 15 - Número 28 - Ano 2014 revistapercursos@gmail.com 